tomáticas da doença, dificultando o diagnóstico. A sua etiologia permanece desconhecida, tornando o seu tratamento um desafio. Descrição do caso clínico: Doente do sexo masculino, 63 anos, com antecedentes de paralisia facial há cerca de 2 anos, enviado à consulta externa de Estomatologia do Centro Hospitalar e Universitário de Coimbra por episódios de repetição de macroquelite do lábio superior e edema da hemiface direita. Já tinha sido realizada biópsia incisional do lábio com resultado inconclusivo e instituído tratamento sistémico com corticosteróide, ao qual o doente respondeu favoravelmente, mas com recidiva da sintomatologia após alguns meses. O estudo de alergias foi negativo. Na consulta, ao exame objetivo, o doente apresentava edema indolor do lábio superior e da hemiface direita, língua fissurada e uma lesão infiltrativa na mucosa jugal, à qual se realizou biópsia por técnica de punch. O exame anátomo-patológico revelou a existência de um infiltrado de linfócitos, mastócitos e raros eosinófilos dispersos, de localização angiocêntrica, com vago padrão granulomatoso, compatível com Síndrome de Melkersson-Rosenthal. Discussão e conclusões: Trata-se de um caso de Síndrome de Melkersson-Rosenthal que, embora em momentos temporais distintos, apresenta os três sintomas característicos da doença - edema orofacial, língua fissurada e paralisia facial. O tratamento da doença depende essencialmente da gravidade das manifestações clínicas, sendo que a maioria dos doentes que apresenta macroquelite beneficia de tratamento tópico, sistémico ou intra-lesional com corticosteróides. O tratamento cirúrgico de remodelação, por vezes, pode ser necessário.

http://doi.org/10.24873/j.rpemd.2020.12.739

\section{\#016 Abcesso Odontogénico com Progressão para Angina de Ludwig, Um Caso Cirúrgico}

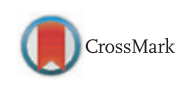

Carolina Carreiro*, Mariana Maia, Rita Martins, Salomé Cavaleiro, Carina Ramos, Mariana Moreira

Serviço de Estomatologia do Centro Hospitalar Universitário de São João

Introdução: A maioria das infeções cervicofaciais tem origem odontogénica. O processo inflamatório progride pelo trajeto que lhe confere menor resistência, podendo disseminar pelos planos fasciais de tecido mole e atingir espaços cervicais profundos. Quando o foco odontogénico é mandibular, o espaço submandibular tem sido consistentemente reportado como o mais afetado. No caso relatado, a disseminação rápida, agressiva e bilateral dos espaços sublingual, submandibular e submentoniano condicionou uma Angina de Ludwig, uma emergência estomatológica. Descrição do caso clínico: Um jovem de 27 anos, do sexo masculino, recorre à urgência do Serviço de Estomatologia no Centro Hospitalar Universitário de São João, por odontalgia no $1 .^{\circ}$ e $4 .^{\circ}$ quadrantes, com 3 dias de evolução. Um dia após início do quadro, surge tumefação submandibular direita, limitação de abertura de boca e febre. Dois dias depois, regista novo agravamento, somando-se disfagia. Ao exame físico, apresenta-se subfebril e com trismo marcado. Palpa-se vo- lumosa tumefação submandibular direita, tensa e dolorosa, que passa a linha média. Identificam-se múltiplas cáries, destacando-se cárie extensa de 4.7 e restos radiculares de $4.8 \mathrm{com}$ abaulamento vestibular e do hemipavimento direito. Em tomografia computorizada é descrita coleção 'submandibular direita, adjacente ao ângulo da mandíbula(...) que se prolonga para região submentoniana(...) sugerindo processo inflamatório (angina de Ludwig)". Analiticamente verifica-se leucocitose, neutrofilia e PCR elevada. Opta-se pelo internamento sob antibioterapia endovenosa. Após diminuição inicial da tumefação submandibular, regista-se nova extensão contralateral e agravamento do trismo, pelo que se procede à extração de 4.7 e restos radiculares de 4.8 , drenagem intraoral e percutânea submandibular, sob anestesia geral. O doente tem alta com resolução clínica e analítica do quadro. Discussão e conclusões: A evolução de infeções odontogénicas frequentemente é imprevisível, sendo o diagnóstico e intervenção adequados, essenciais para minimizar complicações graves. A abordagem inicial da Angina de Ludwig inclui a manutenção da patência da via aérea e tratamento da infeção, com recurso a antibioterapia endovenosa. Ficando a abordagem cirúrgica reservada a casos não responsivos a antibioterapia e com evidência de formação de coleção localizada. No caso descrito, optou-se pelo internamento do doente sob antibioterapia, para monitorização e intervenção cirúrgica.

http://doi.org/10.24873/j.rpemd.2020.12.740

\section{\#017 Fibromatose Gengival Localizada} - a propósito de um caso clínico

Maria João Dias*, Ana Melissa Marques, André Saura, Laura Nobre Rodrigues, Isabel Pina Monteiro, José Pedro Figueiredo

\section{Centro Hospitalar e Universitário de Coimbra}

Introdução: A fibromatose gengival é um aumento gengival de progressão lenta, ocasionado por um crescimento colagenoso excessivo do tecido conjuntivo fibroso gengival. É uma condição rara, que pode ser familiar ou idiopática. As alterações gengivais podem ser generalizadas ou localizadas a um ou mais quadrantes. A maxila é afetada com mais frequência e demonstra um maior grau de aumento, sendo as superfícies gengivais palatinas normalmente mais espessas do que as vestibulares. Nos casos localizados, um padrão distinto e comum envolve a crista alveolar maxilar posterior. Nesse padrão, o tecido hiperplásico forma massas simétricas bilaterais que se estendem posterior e palatinamente às cristas alveolares posteriores. Descrição do caso clínico: Homem, 63 anos, foi encaminhado para a consulta de Estomatologia por tumefação no $1 .^{\circ}$ quadrante, assintomática, desconhecendo o tempo de evolução. Como antecedentes pessoais, refere ser fumador e asmático, medicado com Gibiter ${ }^{\circledR}$ (Fumarato de Folmoterol Budenosida) e Montelucaste. Nega uso de prótese superior ou inferior e nega antecedentes familiares de relevo. Ao exame objetivo, o doente, desdentado parcial superior - Classe II modificada na classificação de Kennedy - apresentava um espessamento gengival bilateral nas superfícies palatinas das cristas alveolares 